\title{
Effect of p-chloromercuribenzoate on protein interaction in heated skimmilk
}

\author{
Umeo Yoshino, Kaname Tanaka, Kunio Yamauchi and Tomokichi Tsugo \\ (Faculty of Agriculture, The University of Tokyo)
}

(Received for Publication on May 9, 1969)

\begin{abstract}
Heating milk results in the various changes on milk proteins and the interaction between protein fractions is also induced. The association of casein with $\beta$-lactoglobulin on heating was reported ${ }^{1,2,8,14}$.

SAwYer et $a l .{ }^{7}$ ) and Purkayastha et al. ${ }^{4)}$ investigated the role of the sulfhydryl (SH) groups in $\beta$-lactoglobulin in formation of protein complex and showed the preventive effect of $\mathrm{N}-$ ethylmaleimide on this reaction. TRAUTMAN and SWANSON ${ }^{9}$ also reported the effect of $p^{-}$ chloromercuribenzoate during forewarming to manufacture evaporated milk on the formation of protein complex, which might influence the stability of evaporated milk.

In this report, p-chloromercuribenzoate (PCMB) was added to milk and its effect on the heat denaturation of proteins in heated milk was investigated.
\end{abstract}

\section{Materials and Methods}

Milk and casein samples: Pooled skimmilk was used throughout this work. Both $\kappa$ - and $\alpha_{s}$-casein fractions were prepared from skimmilk by the urea-sulfuric acid method of ZITTLE and CUSTER ${ }^{13)}$.

Heat treatment of milk: Skimmilk was heated in the tightly closed Erlenmeyer flask or test tube by using a water bath at temperatures ranging from $65^{\circ} \mathrm{C}$ to $95^{\circ} \mathrm{C}$. Then it was cooled rapidly in an ice bath.

Treatment of milk with PCMB: More than $98 \%$ pure p-chloromercuribenzoic acid was obtained from Daiichi Pure Chemicals Co., which was dissolved with $\mathrm{N}$ NaOH before use. Skimmilk was made $0.2 \mathrm{mM}$ with PCMB by adding $5 \mathrm{~m} l$ of $2.2 \mathrm{mM}$ PCMB to $50 \mathrm{~m} l$ of skimmilk. This concentration of PCMB is approximately equivalent to that of SH group of milk reported previously ${ }^{12)}$. The colorimetric method of SASAGO et al. ${ }^{6)}$ to determine the SH content in milk by using $P C M B$ and dithizone was modified and applied for the estimation of the residual PCMB which did not bind with $\mathrm{SH}$ group in skimmilk. The modification made was to make determination of PCMB in the absence of urea.

Sephadex gel filtration: Sephadex G-100 was hydrated in an excess of pH 6.78 phosphate buffer ( 0.10 ionic strength) for $24 \mathrm{hr}$ and added to a $2.7 \mathrm{~cm}$ by $29 \mathrm{~cm}$ chromatographic column. Five $\mathrm{ml}$ of skimmilk was added to the column and eluted at the room temperature with phos. phate buffer, the flow rate being adjusted to $75 \mathrm{~m} l / \mathrm{hr}$. Each $5 \mathrm{~m} l$ fraction was collected and absorbancy at $253.7 \mathrm{~m} \mu$ was measured. The relative area for each peak was calculated by determining either nitrogen or UV absorption of each respective pattern peak.

Polyacrylamide gel electrophoresis (PAE): It was done in the horizontal electrophoresis cell (Fuji Riken Co.). The gel was composed of $7 \%$ Cyanogum in $\mathrm{pH} 9.2$ Tris-borate-4.5 M 


\section{Effect of PCMB on protein interaction}

urea buffer containing EDTA and mercaptoethanol ${ }^{10)}$. Protein sample ( $30 \mu l$ of a $2 \%$ solution) was applied to the gel and run at $200 \mathrm{~V}$ for 7 hours. The gel was cooled with ice during the run.

\section{Results and Discussion}

When skimmilk containing $0.2 \mathrm{mM}$ PCMB was held at $4^{\circ} \mathrm{C}$, the reaction of PCMB with $\mathrm{SH}$ group of skimmilk proceeded as shown in Fig. 1. The reaction reached maximum after about $8 \mathrm{hr}$ at $4^{\circ} \mathrm{C}$, when PCMB bound to SH was $0.15 \sim 0.17 \mathrm{~mm}$. As the value of $0.18 \sim 0.20 \mathrm{~mm}$ was reported for $\mathrm{SH}$ content of milk $^{12}$, most of $\mathrm{SH}$ was considered to have bound with the added PCMB. SASAGo et al. ${ }^{6)}$ have shown that the reaction between PCMB and milk or $\beta$-lactoglobulin reached a maximum value in about $24 \mathrm{hr}$ in phosphate buffer at $\mathrm{pH}$.

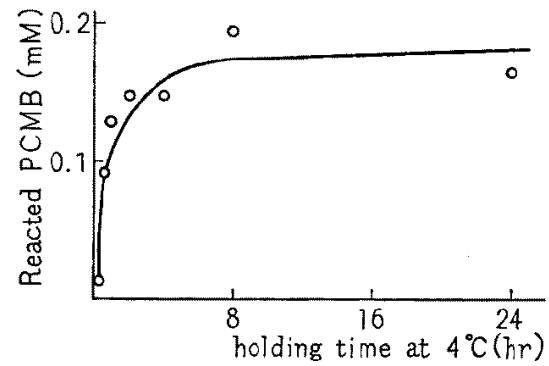

Fig. 1. Effect of holding at $4^{\circ} \mathrm{C}$ on the reaction between PCMB and skimmilk

Heating milk results in the denaturation of whey protein and decreases the non-casein nitrogen (NCN). Skimmilk made $0.2 \mathrm{~mm}$ with PCMB was heated and NCN was determined by the method of RowLAND ${ }^{5)}$ and expressed as \% of NCN of the unheated skimmilk. The results were shown in Fig. 2. When heated at $80^{\circ} \mathrm{C}$ for $10 \mathrm{~min}, \mathrm{NCN}$ for skimmilk treated with

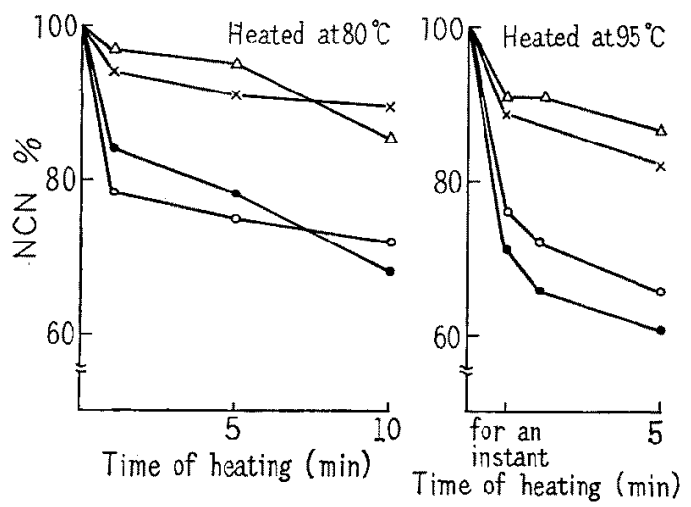

Fig. 2. Effect of PCMB treatment on the content of noncasein nitrogen ( $\mathrm{NCN}$ ) in heated skimmilk. $\mathrm{NCN}$ of unheated skimmilk was expressed as $100 \%$

- - heated without the addition of PCMB

- - - heated soon after the addition of PCMB

$-\times-$ heated after $8 \mathrm{hr}$ 's holding at $4^{\circ} \mathrm{C}$ with $\mathrm{PCMB}$

$-\triangle-$ heated after $24 \mathrm{hr}$ 's holding at $4^{\circ} \mathrm{C}$ with $\mathrm{PCMB}$ 
PCMB for 8 and $24 \mathrm{hr}$ at $4^{\circ} \mathrm{C}$ before heating were $89.5 \%$ and $85.2 \%$ of that of unheated milk, respectively. These values were about $20 \%$ more than that of milk heated in the absence of PCMB. For the milk heated for $95^{\circ} \mathrm{C}$ for $5 \mathrm{~min}$, the similar difference in NCN was also observed between PCMB-treated and untreated (control) milk. From these results, it is assumed that PCMB prevents the denaturation of whey protein and retains more NCN in heated milk. But, when skimmilk was heated at $80^{\circ} \mathrm{C}$ or $95^{\circ} \mathrm{C}$ soon after the addition of PCMB, such effect of PCMB to prevent whey protein denaturation on heating milk was not found. The difference between NCN of these skimmilk samples and that of control milk were only about $4 \%$.

When skimmilk was heated at $65^{\circ} \mathrm{C}, 80^{\circ} \mathrm{C}$ or $95^{\circ} \mathrm{C}$ soon after the addition of $0.2 \mathrm{mM}$ PCMB, the reaction of PCMB was, as shown in Table 1 , about $0.15 \mathrm{mM}$. This value does not differ much from the results (Fig. 1) obtained with unheated milk held at $4^{\circ} \mathrm{C}$ for more than $8 \mathrm{hr}$ in the presence of PCMB. In spite of that the amount of reacted PCMB was apparently same, however, the effect of PCMB to prevent the heat denaturation of whey protein was not found in NCN determination of skimmilk which was heated soon after the addition of PCMB. These results suggest the possibility that, in such a milk sample, PCMB binds rather to other activated sites of protein than to $\mathrm{SH}$. There might be a competition between $\mathrm{SH}$ and other heat activated sites of protein to react with PCMB.

Table 1. Effect of heating on the reaction of PCMB in skimmilk

\begin{tabular}{l|c|ccc|ccc|c}
\hline \multicolumn{1}{c|}{ Temperature } & \multirow{2}{*}{ Unheated } & \multicolumn{3}{|c|}{$65^{\circ} \mathrm{C}$} & \multicolumn{3}{|c|}{$80^{\circ} \mathrm{C}$} & $95^{\circ} \mathrm{C}$ \\
\cline { 2 - 8 } Time (min) & & 10 & 20 & 30 & 2 & 5 & 10 & $\begin{array}{c}\text { For an } \\
\text { instant }\end{array}$ \\
\hline Reacted PCMB (mM) & 0.017 & 0.115 & 0.128 & 0.153 & 0.144 & 0.162 & 0.189 & 0.156 \\
\hline
\end{tabular}
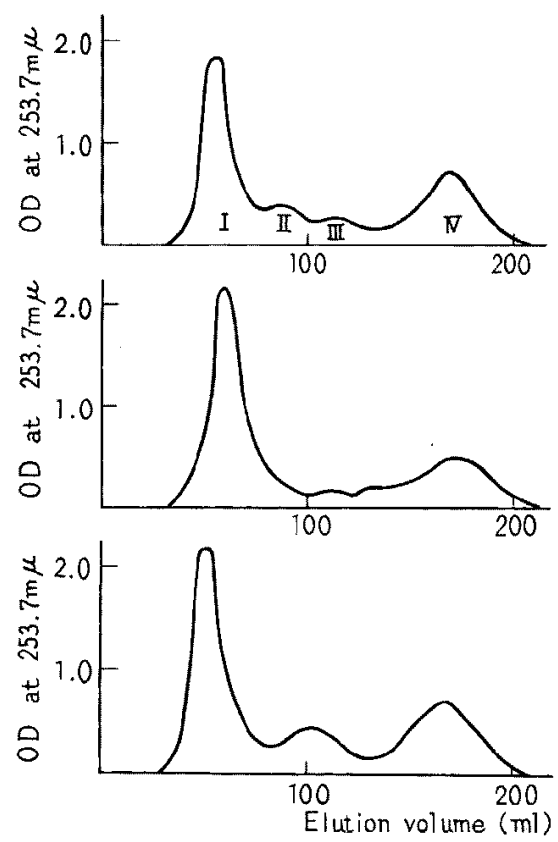

Fig. 3. Sephadex G-100 gel filtration patterns of skimmilk

Top: unheated

Middle: heated at $95^{\circ} \mathrm{C}$ for $5 \mathrm{~min}$

Bottom: heated at $95^{\circ} \mathrm{C}$ for $5 \mathrm{~min}$ after $24 \mathrm{hr}$ 's holding at $4^{\circ} \mathrm{C}$ with $\mathrm{PCMB}$ 


\section{Effect of PCMB on protein interaction}

The gel filtration pattern of skimmilk by Sephadex G-100 is shown in Fig. 3. Unheated skimmilk was fractionated by Sephadex G-100 to four components. When milk was heated at $95^{\circ} \mathrm{C}$ for $5 \mathrm{~min}$, Components II and III decreased and their boundary became obscure. For the milk treated with PCMB at $4^{\circ} \mathrm{C}$ for $24 \mathrm{hr}$ and heated at $95^{\circ} \mathrm{C}$ for $5 \mathrm{~min}$, Components II and III combined each other to make a single peak, the relative area of which was greater than with milk heated in the absence of PCMB. For the milk samples heated at $65^{\circ} \mathrm{C}$ or $80^{\circ} \mathrm{C}$ with and without the added PCMB, the similar Sephadex G-100 gel filtration patterns were obtained.

Table 2. Effect of heating and PCMB on the Sephadex G-100 gel filtration patterns of skimmilk

\begin{tabular}{l|c|ccc|ccc}
\hline \multicolumn{2}{c|}{ Sample preparations } & \multicolumn{3}{|c|}{ Relative area of each component $\%$ of total) calculated } \\
\hline \multirow{2}{*}{$\begin{array}{c}\text { Heating } \\
\text { condition }\end{array}$} & $\begin{array}{c}\text { PCMB } \\
\text { (mM) }\end{array}$ & \multicolumn{2}{|c|}{ by nitrogen determination } & \multicolumn{3}{|c}{ by UV absorption } \\
\cline { 3 - 8 } & 0 & 69.3 & 23.2 & 7.5 & 59.3 & 16.2 & 24.5 \\
\hline Unheated & 0 & 76.6 & 14.8 & 8.6 & 53.3 & 15.9 & 30.8 \\
\hline \multirow{3}{*}{$65^{\circ} \mathrm{C}, 30 \mathrm{~min}$} & 0.2 & 71.4 & 20.9 & 7.7 & 56.1 & 16.6 & 27.3 \\
& 0 & 74.9 & 17.0 & 8.1 & 59.4 & 13.8 & 26.8 \\
$80^{\circ} \mathrm{C}, 10 \mathrm{~min}$ & 0.2 & 73.0 & 17.7 & 9.3 & 57.0 & 16.7 & 26.3 \\
& 0 & 82.7 & 9.4 & 7.9 & 64.5 & 10.5 & 25.0 \\
$95^{\circ} \mathrm{C}, 5 \mathrm{~min}$ & 0.2 & 72.4 & 17.6 & 10.0 & 60.3 & 15.2 & 24.5 \\
\hline
\end{tabular}

The relative area of each component was tabulated in Table 2. The differences were observed between the relative area of peaks of gel filtration patterns calculated by nitrogen determination and UV absorption. It is due to the difference in relative proportion of aromatic amino acids in each peak ${ }^{81}$.

The sum of relative area of Components II and III, calculated either by nitrogen or UV absorption, decreased in heated milk. In the milk heated after treatment with PCMB, the decrease in the relative area of Components II and III was less than with milk heated in the absence of PCMB.

According to MoRR et al. ${ }^{\text {s) }}$, Component I in fractionation of skimmilk with Sephadex G-100 contains caseinate and large sized serum protein such as globulins. Components II and III are mainly $\beta$-lactoglobulin and $\alpha$-lactalbumin, respectively, and Component IV is non protein fraction. The fact that the relative area for Components II and III in Sephadex pattern of heated milk is smaller than with the unheated milk is due to the denaturation and aggregation of whey proteins. The decrease of Components II and III is consistent with the lower NCN content in heated milk. The added PCMB seems to possess a preventive effect on such a type of heat denaturation of whey protein.

In the PAE pattern of Component I of heated skimmilk, the band corresponding to $\kappa$-casein disappeared (Fig. 4). But, with milk heated after PCMB treatment, $\kappa$-casein was detected in PAE pattern. This result suggests that $\kappa$-casein is one of the fractions to interact with whey protein on heating milk.

In the previous paper ${ }^{11)}$, it was shown that $\kappa$-casein fraction prepared from heated milk did not possess the $\alpha_{s}$-casein stabilizing ability. The loss of stabilizing ability of $\kappa$-casein was thought not to be due to the heat denaturation of $\kappa$-casein itself, but to be resulted from the 


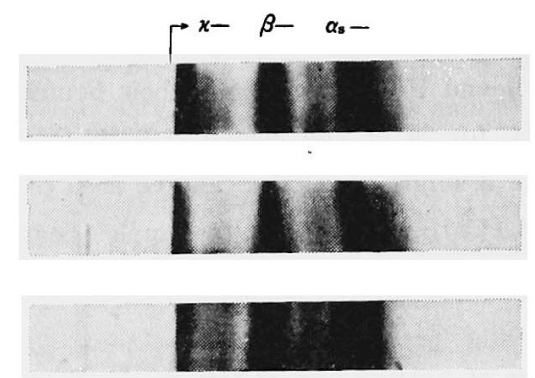

Fig. 4. Polyacrylamide gel electrophoresis patterns of Component I of skimmilk fractionated with Sephadex G-100 (see Fig. 3)

Top: Component I of unheated skimmilk

Middle: Component I of skimmilk heated at $95^{\circ} \mathrm{C}$ for $5 \mathrm{~min}$ Bottom: Component I of skimmilk heated at $95^{\circ} \mathrm{C}$ for $5 \mathrm{~min}$ after $24 \mathrm{hr}$ 's holding at $4^{\circ} \mathrm{C}$ with PCMB

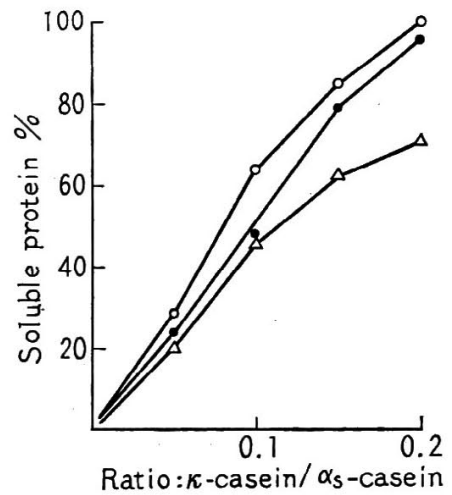

Fig. 5. $\alpha_{s}$-Casein stabilizing ability of $\kappa$-casein fractions $-\mathrm{O}-\boldsymbol{\kappa}$-casein fraction prepared from unheated skimmilk $-\Delta-\kappa$-casein fraction prepared from skimmilk heated at $80^{\circ} \mathrm{C}$ for $10 \mathrm{~min}$

- - $\kappa$-casein fraction prepared from skimmilk heated at $80^{\circ} \mathrm{C}$ for $10 \mathrm{~min}$ after $24 \mathrm{hr}$ 's holding at $4^{\circ} \mathrm{C}$ with PCMB

heat-induced interaction of $\boldsymbol{\kappa}$-casein and whey protein. The $\boldsymbol{\kappa}$-casein fraction prepared from milk heated at $80^{\circ} \mathrm{C}$ for 10 min after treatment with PCMB was tested for $\alpha_{s}$-casein stabilizing ability by using the method described previously ${ }^{11)}$. As shown in Fig. 5, it retained the full stabilizing ability.

The loss of the stabilizing ability of $\kappa$-casein fraction of heated milk, the decrease of NCN, disappearence of $\kappa$-casein band in PAE pattern and the decrease of whey protein fraction in Sephadex gel filtration pattern were observed in heated milk. These changes were considerably prevented by the treatment of milk with PCMB before heating. PCMB may combine with $\mathrm{SH}$ groups in milk and prevent the formation of protein complex. Though the mechanism of interaction of whey protein with casein on heating had not been clearly explained yet, SH had been thought to play an important role. SAWYER et al. ${ }^{7)}$ suggested the formation of an intermolecular disulfide bond between two proteins, and found the preventive effect of $\mathrm{N}$-ethylmaleimide on this reaction. 
The reaction of PCMB with $\mathrm{SH}$ group of milk or $\beta$-lactoglobulin is rather slow in the absence of protein denaturing agents ${ }^{6}$. When milk was heated soon after the addition of PCMB, the preventive effect of PCMB on the protein interaction was not observed. The formation of intermolecular disulfide bond might proceed faster than the reaction of PCMB with SH in heated milk.

\section{Summary}

The effect of PCMB on the interaction of milk proteins induced by heat-treatment was investigated.

Skimmilk was made $0.2 \mathrm{mM}$ with $\mathrm{PCMB}$ and held at $4^{\circ} \mathrm{C}$ for 8 to $24 \mathrm{hr}$ before heating. $\mathrm{PCMB}$ treated milk was then heated at temperatures ranging from $65^{\circ} \mathrm{C}$ to $95^{\circ} \mathrm{C}$ and the nitrogen distribution, Sephadex gel filtration, PAE patterns and the stabilizing ability of $k$-casein prepared from it were studied.

The decrease of $\mathrm{NCN}$ by heating milk at $80^{\circ} \mathrm{C}$ for $10 \mathrm{~min}$ and $95^{\circ} \mathrm{C}$ for $5 \mathrm{~min}$ were $10.5 \%$ and $14.8 \%$, respectively, in PCMB treated milk, while those of control (heated in the absence of PCMB) milk were $31.9 \%$ and $39.5 \%$, respectively. This preventive effect of PCMB on the heat denaturation of whey protein was also found in Sephadex G-100 gel filtration patterns of heated milk, that is, the relative area of components corresponding to whey proteins was larger in PCMB treated milk than with control milk.

The results of PAE showed that $\kappa$-casein interacted with other protein fractions in heated milk, this interaction being inhibited in PCMB treated milk.

$\kappa$-Casein prepared from heated milk did not possess the $\alpha_{s}$-casein stabilizing ability, but, from heated PCMB treated milk, $\kappa$-casein with the full stabilizing ability was obtained.

When skimmilk was heated soon after the addition of PCMB, the preventive effects of PCMB on whey protein denaturation were not found. In this case, PCMB might react non-specifically with the heat activated sites other than SH in heated milk.

\section{References}

1) Long, J.E., Q. Van Winkle and I.A. Gould (1963) J. Dairy Sci., 46: 1329-1334.

2) Mcgugan, W.A., V.F. Zehrin, V.L. Zehren and A.M. Swanson (1954) Science, 120: 435.

3) Morr, C.V., D.B. Kenkare and I.A. Gould (1964) J. Dairy Sci., 47: 621-625.

4) Purkayastha, R., H. Tessier and D. Rose (1967) J. Dairy Sci., 50: 764-766.

5) Rowlamd, S.J. (1938) J. Dairy Res., 9: 42-46.

6) Sasago, K., H.K. Wilson and E.O. Herreid (1963) J. Dairy Sci., 46: 1348-1351.

7) SAWYer, W.H., S.T. Coulter and R. Jenness (1963) J. Dairy Sci., 46: 564-565.

8) Trautman, J.C. and A.M. Swanson (1958) J. Dairy Sci., 41: 715.

9) Trautman, J.C. and A.M. Swanson (1959) J. Dairy Sci., 42: 895.

10) Wочснік, J.H. (1965) Arch. Biochem. Biophys., 109: 542-547.

11) Yoshino, U., S. TAkemoto, K. Yamauchi and T. Tsugo (1969) Jap. J. Zootech. Sci., 40: 299-303.

12) Yoshino, U., H.K. Wilson and E.O. Herreid (1962) J. Dairy Sci., 45: 1459-1464.

13) Zittie, C.A. and J.H. Custer (1963) J. Dairy Sci., 46: 1183-1188.

14) Zittle, C.A., M.P. Thompson, J.H. Custer and J. Cerbulis (1962) J. Dairy Sci., 45: 807-810. 


\title{
牛乳蛋白質の加熱変性におよぼすパラクロル水銀安息 香酸 (PCMB) の影響
}

\author{
吉野梅夫・田中 要 - 山内邦男 - 津郷友吉
}

(東京大学患学部)

牛乳加熱時の蛋白算の相互作用に刘す万 $\mathrm{PCMB}$ の影 留定調バた。

脱脂乳に PCMB 定 $0.2 \mathrm{mM}$ 添加し, $4^{\circ} \mathrm{C}$ で 8 24 侍

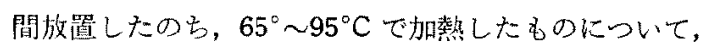
非カゼイン態窒秦（NCN）这測定し，さらに Sephadex G-100によるダル沪過，ポリアクリルアミドダル電気涾

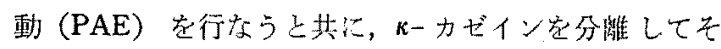
の $\alpha_{s}$ 力ゼイン安定化力它調べた。

PCMB で処理した脱脂乳は $80^{\circ} \mathrm{C}, 10$ 分または $95^{\circ} \mathrm{C}$, 5 分の加熱により， NCN は $10.5 \%$ または $14.8 \%$ の減 少定示すのみで， PCMB 定添加しないで加熱した脱脂 乳では $31.9 \%$ または $39.5 \%$ の咸少が浔められたのにく らべ，明らかに差がある。このようなホェ一蛋白貿の熱 变性を组止する PCMB の奻果は Sephadex G-100によ るゲル沪過でも認められた。すなわち，加熱脱脂乳の
Sephadex による分別に和いで，ホエー蛋白質に相当す る成分【および开の相対量が減少するが， PCMB 処理 後に加熱した場合はその娍少度は小さくなる。成分Iは カゼインに相当するが，加熱脱脂乳の成分 I $の$ PAE で Uкーカゼインに相当する成分が消失し，PCMB 処理後

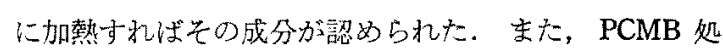
理後に加埶した脱脂乳から調製した カゼイン安定化力主保有していた。

以上のようにホエー蛋白質の变性で説明できるような 牛乳加熱洔の諸变化に対し， PCMB 加阻止作用定有す るここが確珰された。ただし，PCMB を添加した直後 に加熱した場合にはその阻止作用性認めら机ず，この場 合比 PCMB はSH 基とではなく，加熱により活性化 した他の反応基と結合している可能性曲考えられる。 